\title{
Effect of enzyme supplementation and plant extracts on villus height and microbial counts in broilers
}

Ofongo, R. T. S. and ${ }^{2}$ Ohimain, E. I.

${ }^{1}$ Poultry Nutrition and Animal Biotechnology research group, Department of Animal

Science, Faculty of Agriculture, Niger Delta University, Wilberforce Island, P.M.B 071

Yenagoa, Bayelsa State - Nigeria

${ }^{2}$ Veterinary \& Agricultural Microbiology Research Unit, Department of Biological

Sciences, Faculty of Science Niger Delta University,

Wilberforce Island, P.M.B 071 Yenagoa, Bayelsa State - Nigeria

*Corresponding author: tariruth@live.de; ruthofongo@gmail.com;

Abstract $\quad 08158683316 ; 08038827764$

Due to issues concerning antimicrobial resistance, the use of antibiotics in poultry and pigs has been restricted in many countries. The research focus is now on suitable and readily available alternatives to antibiotic growth promoters. Alternatives such as probiotic, prebiotic, synbiotic, enzymes and acidifiers are being utilized while Phyto biotics (plant extracts) are also considered as viable alternatives. In this study, leaf extracts of Azadirachta indica (neem) and Vernonia amygdylina (bitter leaf) were administered through drinking water, while enzyme (Roxazyme $G 2 G^{\circledR}$ ) was supplemented in the feed of different groups of broiler birds which were randomly allocated to three treatments and a control in triplicates of ten birds per replicate. The control group did not receive either plant extract in water or enzyme in their diet. On day 42, the chickens were slaughtered; the digesta was gently collected from the ileum and caecum for microbial analysis, while histological analysis was carried on the empty ileum for the determination of villus height. Data collected for microbial analysis was log transformed before statistical analysis and was stated as Log colony forming unit/g of digesta sample (Log cfu/g). The highest villus height was recorded for enzyme treatment $(0.955 \mathrm{~mm})$ followed by bitter leaf $(0.717 \mathrm{~mm})$, and least for neem leaf $(0.592 \mathrm{~mm})$ with $0.656 \mathrm{~mm}$ for the control. Enzyme supplementation, bitter leaf and neem leaf extract administration had no significant effect $(p>0.05)$ on villus height. However, villus height recorded for enzyme supplementation and administration of bitter leaf extract was numerically higher than the control group. The population of total heterotrophic bacteria $(T H B)$ in the ileum was significantly higher $(p<0.05)$ in the control group $(9.28$ Log cfu/g) than enzyme supplementation (8.52 Log cfu/g) and administration of leaf extract. The least value was recorded was recorded with bitter leaf (7.94 Log cfu/g). A value of $8.14 \mathrm{Log}$ cfu/g was recorded with neem extract in drinking water. Total coliform was significantly higher $(p<0.05)$ in the control $(7.33 \mathrm{Log} c f u / g)$ than in enzyme (6.00 Log cfu/g), neem leaf (4.74 Log cfu/g) and bitter leaf $(4.84 \mathrm{Log} c f u / g)$ treatments. The population of enteropathogenic bacteria (Escherichia coli and Salmonella) was also significantly reduced $(p<0.05)$ by enzyme supplementation and administration of neem leaf and bitter leaf extracts in the ileum. The THB and total coliform counts (Log cfu/g) was significantly $(p<0.05)$ reduced by enzyme supplementation, neem leaf and bitter leaf extract in the caecum also. In conclusion, the results of the current study showed that the leaf extracts and enzyme supplementation significantly decreased the number of enteropathogenic bacteria in the ileum and caecum. Although there was no significant impact on villi height, but numerical difference in villi height were recorded.

Keywords: Broilers, enzyme, Phyto biotic, intestinal villi height 


\section{Effect of enzyme supplementation and plant extracts}

\section{Introduction}

Poultry is one of the most important sources of animal protein globally. Chicken is consumed by virtually every tribe, race or religion, almost without any forms of restriction. Unlike red meat, chicken meat is often considered as a healthier form of animal protein. Notwithstanding the importance of poultry in human nutrition, poultry farming is threatened by high cost of feeds and microbial infections. Some detrimental microbes causing infections in poultry include Salmonella, Escherichia coli (E. coli), Clostridium and Eimeria, while others such as Lactobacillus, Saccharomyces and Bifidobacteria are considered as beneficial microbes. The use of antibiotic growth promoters (AGP) are either restricted or out rightly banned in many countries (Nabizadeh, 2012; Stanley et al., 2014). Hence, poultry farmers are faced with the challenge of how to effectively control bacterial infections while boosting performance.

Current research is focused on the development of alternative feed stocks that are cheap, readily available and the use of supplements for control of infections. Several promising alternative feed stocks and infection control strategies have emerged including enzymes (Ohimain and Ofongo, 2013; Ofongo et al., 2016), probiotics (Ohimain and Ofongo, 2012), prebiotics (Nabizadeh, 2012), synbiotics (Awad et al., 2009; Padihari et al., 2014; mushrooms (Ogbe et al., 2009; 2010; Willis et al., 2010a, 2010b, 2011) and botanicals (Incharoen et al., 2009; Ogbe and Affiku, 2012; Ohimain et al., 2015; Ofongo and Ohimain, 2015) and combination of these and other growth promoters (Dizaji et al., 2013; Pelicano et al., 2015; Hashemi et al., 2014).

In the recent, the importance of the gastrointestinal tract (GIT) health in overall performance of broiler chicken is increasingly being recognized (Dizaji et $a l ., 2013)$. The intestinal epithelium acts as a barrier protecting the animal against pathogenic microbes and toxic substances ingested (Pelicano et al., 2005). According to Awad et al. (2008), probiotics act by reinforcing the intestinal mucosal barrier against pathogenic microbes and toxic substances, while prebiotics selectively stimulate the activities of beneficial microbes in the mucosal surfaces (Awad et al., 2008; Pelicano et al., 2005). Stanley et al. (2014) opined that probiotics and prebiotics enhance the development of villus height of broilers. They reported that prebiotics and probiotics increase the height of villus in chicken. Dietary consumption also affects the villus height of broilers. While the study of Laudadia et al. (2012) demonstrated that high dietary protein levels of $20.5 \%$ resulted in higher villus height and villus height to crypt depth ratio in duodenum and ileum of chicken. According to other authors, (Incharoen et al., 2010) a decrease in villus height in the duodenum and ileum when chickens were fed low protein diet containing $9.4 \%$ crude protein was observed. However, a previous study by Incharoen et al. (2009) reported an increase in performance and histological changes resulting in increased villus height, villus area, and cell area following feed substitution with natural zeolite containing plant extracts. A study by Hashemi et al. (2014) reported that broiler villus height increases when the feed was supplemented with a combination of herbal plant (Euphorbia hirta) and a mix of acidifier. According to Nabizadeh (2012), administration the prebiotic inulin to broiler chickens had no effect on Bifidobacteria, Lactobacillus and E. coli counts in ileal contents, but significantly increased Bifidobacteria and decreased the E. coli counts in caecal contents. The authors reported significantly increased villus height at the ileum and increased performance with inulin administration. 


\section{Ofongo and Ohimain}

Padihari et al. (2014) showed that a combination of the probiotic Saccharomyces cerevisiae and the prebiotic manan oligosaccharide resulted in significant increase in villus height at the duodenum, jejunum and ileum of broiler chickens. A study by Yamauchi et al. (2010) indicated that compensatory enlargement of villus can be induced in chickens after $50 \%$ or $80 \%$ jejunal resection and also after $50 \%$ jejunal plus $70 \%$ ileal resection. Apart from all these positive effects on villus height, certain other substances used in poultry feeding can be detrimental to the villus such as hormones. The work of $\mathrm{Hu}$ and Guo (2008) revealed that the administration of corticosterone resulted in a significant decrease in the villus height at the duodenum and jejunum of broiler chickens. Hence, in this study, we investigated the effects of enzyme supplementation and plant extract administration on villus height and microbial counts in broilers.

Materials and methods Management of experimental birds

A total of 120 mixed sex one-day old
(ANAC 2000) broiler chicks were purchased for the purpose of the experiment. The birds were randomly distributed to four treatments having three replicates of 10 birds per replicate at the end of the brooding period (seven days). The birds were given a commercial broiler starter diet for four weeks after which they were given a broiler finisher diet for two weeks. The birds in treatment 1 assigned as the control were fed the commercial broiler diet but were not given any leaf extract nor their diet supplemented with enzyme. Treatment two was designated as birds fed enzyme (Roxazyme G2 G (B) supplemented Feed. In treatment three, birds were administered neem leaf (Azadirachta indica) extract and in treatment four, birds were administered bitter leaf (Vernonia amygdylina) extract.

Source of additives used (Enzyme, neem leaves and bitter leaf extracts)

Nutrient Composition of the feed (finisher) used is as indicated in Table 1. The feed was maize/soy bean meal based.

Table 1: Nutrient Concentration of feed used (all values in $\mathrm{g} / \mathrm{kg}$ DM, except otherwise indicated)

\begin{tabular}{lc}
\hline Feed ingredient & Concentration \\
\hline Maize & 550 \\
SBM & 330 \\
Fish meal & 40 \\
Cassava starch & 42 \\
Constant ingredients* & 38 \\
Total & $\mathbf{1 0 0 0}$ \\
Calculated nutrient composition & \\
M.E (Kcal/kgDM & 3028.5 \\
Crude protein & 214.94 \\
Analyzed composition & \\
Crude protein & 210.85 \\
Ash & 46.8 \\
Ether extract & 69.8 \\
Crude fibre & 65.70 \\
Nitrogen free extract & 609.2 \\
Dry matter & 947.60 \\
\hline *: bone meal (21g); oyster shell (10g); vitamin/mineral premix (2.5g);DL methionine (1.5g); common salt (3g)
\end{tabular}




\section{Effect of enzyme supplementation and plant extracts}

The enzyme was added at an inclusion rate of 200ppm to complete feed. It is a nonstarch polysaccharide (NSP) degrading enzyme (Roxazyme G2 G®). It is an odorless granulate which is soluble in water. It contains an enzyme complex derived from Trichoderma longibrachiatum. It has an effective $\mathrm{pH}$ of 3.5 to 5.5 and temperature range of 30 $55^{\circ} \mathrm{C}$.

The leaves of Azadirachta indica (neem) and Vernonia amygdylina (bitter leaf) were obtained from the University Teaching and Research farm. The leaves were individually weighed $(10 \mathrm{~g})$ with a digital weighing scale, washed in clean water, milled with electric blender. It was then sieved using a cheese cloth to remove particles from the liquid. The extracted liquid $(75 \mathrm{~mL})$ was then divided into three equal proportions and added to the drinking water.

\section{Digesta Collection}

On day 42, a total of twelve birds twelve -3 birds per replicate were slaughtered by cervical dislocation. Digesta was gently collected from the ileum and caecum and placed into sterile sampling container then placed on ice prior to transfer to the laboratory microbial analysis. The ileum flushed with $0.9 \%$ saline, the empty ileum and caecum were stored in $10 \%$ formaldehyde for determination of villus height.

\section{Determination of Villus height from the ileum samples}

The intestines of the birds were fixed in $10 \%$ formaldehyde for 72 hours (three days). This will slowly penetrate the tissue causing chemical and physical changes that will harden and preserve the tissue and protect it against subsequent processing steps. The fixed tissues were sent to the cutup room where cross sections of the specimen were made $(4-5 \mathrm{~mm})$ thick and each was placed on tissue cassettes. These cassettes were labeled according to the labels on the specimen containers. The tissues were manually processed (animals' samples are easily fragmented).

The tissue specimens were dehydrated to remove all the water molecules in it before embedding in paraffin wax. The dehydration methods were carried out with graded alcohol ranging from $70 \%$ to $100 \%$ in a sequential order. The tissue went through six stages in this step to achieve an almost water-free state within 2 hours, 15 minutes.

Since ethanol is an organic solvent miscible with water, it is also immiscible with wax and this step is to displace ethanol from the tissues. This procedure is called clearing and is done using xylene which is miscible with wax and also helps to dissolve fat molecules that may prevent wax infiltration of the tissue. These tissues are placed in xylene in three stages; this depended on about a cumulative time of 1 hour, 25minutes in this stage 20, 20 and 45 minutes respectively.

The specimens were now infiltrated with molten histological wax at temperature of $60^{\circ} \mathrm{C}$. These displaced all the clearing agents and make the tissues firm and ready for embedding. Embedding requires filing a mold with wax and placing the specimen on the molten wax which hardens and form tissue block that can be clamped on microtomes for tissue sectioning. The most important consideration here was that specimen must be well oriented on the block to pre-determine the plane section. For an intestinal tissue the circumference of the intestine is targeted so that the villi radiate perpendicularly into lumen from where the villus length can be determined.

Sectioning of the tissues was done with tissue microtome (Leica). These were cut into thin sections measuring $2-3 \mu \mathrm{m}$ each. Several sections were made and placed in a water bath set at a predetermined 


\section{Ofongo and Ohimain}

temperature usually between the ambient temperature and the melting point of paraffin wax. In this procedure, the water bath temperature was $55^{\circ} \mathrm{C}$. This helps to evenly spread the tissue section and prevent folding artifact formation.

The tissue section was picked up with a glass slide and placed on a drier. This facilitates the adherence of the tissue to the glass slide and melting away of the residual wax. The slides containing paraffin sections were placed in a slide holder (glass or metal), the tissue specimen was deparaffinized and rehydrated with reverse concentration of ethanol (100\% to $70 \%)$. The slides were stained with hematoxylin and Eosin which impacts a red and navyblue colour to the tissues. The tissues were then mounted with a mountant (DPX) and covered with a thin glass cover-slip and allowed to dry.

Using Leica DM 750M, the villus length was measured at X10 objective lens. Minimum of fifteen (15) villi were measured per sample and the average length were calculated. The microscopic measurements were re-converted to expect actual length by dividing with a factor of the objective lens magnification. Villus height was carried out on per replicate basis with regards to each treatment. Values recorded were then used for statistical analysis.

\section{Population of gut microorganisms}

The populations of microorganisms in the different samples were enumerated using serial dilution pour plate method of Pepper and Gerba (2005). One-gram (1g) of digesta sample was serially diluted in sterile distilled/deionized water and aliquots of the dilutions were aseptically plated into growth media; MRS (de Man Rogosa and Sharp) Agar supplemented with cycloheximide to enumerate total lactobacillus species. The media were anaerobically incubated at $30^{\circ} \mathrm{C}$ for seven days. For the isolation of E. coli, EMB
(Eosin Methylene Blue) Agar was employed and it was incubated aerobically at $30^{\circ} \mathrm{C}$ for 24 hours. Salmonella-Shigella Agar was used to enumerate total Salmonella population. The medium was incubated aerobically at $30^{\circ} \mathrm{C}$ for 24 hours; however, presence of black colonies indicated Salmonella species, Wile pink colonies indicate Shigella. On EMB agar, the presence of greenish metallic sheen with small nucleated colonies indicate the presence of E. coli (Pepper and Gerba, 2005; Benson 2002). After incubation, the colonies that grew on the medium were counted and expressed as colony forming units $(\mathrm{cfu}) / \mathrm{g}$ of the samples. Also, the frequency of $E$. coli from the EMB agar plate was computed and Salmonella from Salmonella-Shigella counts was determined.

\section{Statistical analysis}

The bacteria count was log transformed before carrying out statistical analysis. SPSS software version 20 (IBM SPSS Inc, Chicago) was used to carry out the statistical analysis on the microbial counts. A one-way analysis of variance was carried out at $P \leq$ 0.05 , and Duncan multiple range tests was used for multiple comparisons.

\section{Results and discussion Villus height}

Histopathological pictures of ileum sections are presented in Figures 1 - 4, while the villi height measurements are presented in Table 2 . The highest villus height was recorded for enzyme treatment $(0.955 \mathrm{~mm})$ followed by bitter leaf $(0.717 \mathrm{~mm})$, and least for neem leaf $(0.592 \mathrm{~mm})$ but these apparent differences were not significant $(p>0.05)$ among all the treatments including the control (0.656mm). Dizaji et al. (2013), reported significantly different villi $(p<0.01)$ when different growth promoters were administered to chickens including prebiotic $(1.693 \mathrm{~mm})$, probiotic $(1.610 \mathrm{~mm})$, 


\section{Effect of enzyme supplementation and plant extracts}

synbiotic $(1.732 \mathrm{~mm})$ and acidifier $(1.760 \mathrm{~mm})$. Award et al (2008), reported significantly different villi heights at the ileum $(0.774 \mathrm{~mm})$ and duodenum $(1.647 \mathrm{~mm})$ when synbiotic containing Enteroccocus faecium and oligosaccharides were incorporated in broiler feeds. From these studies, it therefore appears that alternative feed additives could affect intestinal structure and functions. But in our study the apparent differences observed were not significant. Probable reasons for this remain unclear. Earlier reports by Hashimi et al. (2014) concluded that the combination of herbal plant and acidifier results in enhanced maintenance and function of the small intestine and hence broiler performance. According to Mounia et al. (2018) gut morpho-histological structure of broiler chickens given $50 \mathrm{ml}$ of phytogenic products / 50 chicks in water for 42 days resulted in decreased villi height of the duodenum, jejunum and ileum (1230 ì $\mathrm{m} \pm 270,1127$ ì $\mathrm{m} \pm 290,920$ ì $\mathrm{m} \pm 220$ ) respectively. In essence, gut morphohistological response to administration of plant extract may differ as indicated in the results obtained from the study. Earlier published performance data by Nodu et al. (2016) reported that, administering $3 \mathrm{~g}$ of neem leaf per litre of water to broiler birds encouraged healthy growth in the birds and thus could serve as alternative for antibiotics in areas with limited access to veterinary services. Administration of $5 \mathrm{~g}$ of Vernonia amygdylina (bitter leaf) per litre of drinking water to 8 weeks old broilers resulted in improved weight gain and feed conversion ratio over birds in the control group without (unpublished data).

Table 2: Villus heights $(\mathrm{mm})$ of birds in various treatments

\begin{tabular}{lcc}
\hline Treatment & Mean $(\mathrm{mm})$ & standard deviation \\
\hline control & $0.65600^{\mathrm{ns}}$ & 0.088 \\
Enzyme & $0.95500^{\mathrm{ns}}$ & 0.447 \\
Neem leaf & $0.59267^{\mathrm{ns}}$ & 0.122 \\
Bitter leaf & $0.71767^{\mathrm{ns}}$ & 0.114
\end{tabular}

NS: Not Significantly different $(p>0.05)$

\section{Gut bacteria population}

The population of total heterotrophic bacteria (THB) was significantly higher $(p<0.05)$ in birds under the control treatment compared to enzyme supplementation and administration of leaf extracts respectively (Table 3 ). In the ileum, the highest population of THB was recorded at the control $(9.23 \pm 0.38)$ followed by enzymes $(8.52 \pm 0.33)$, while the least value of $7.94 \pm 0.38$ was recorded when bitter leaf extract was administered. This same pattern was not observed for the total coliform where the highest population was recorded in the control (7.33 Log cfu/g) followed by enzyme supplementation $(6.00$ Log cfu/g) and lowest in neem (4.74 Log $\mathrm{cfu} / \mathrm{g})$ and bitter leaf (4.84 Log $\mathrm{cfu} / \mathrm{g})$ extracts $(p<0.05)$.

Table 3: Microbial count ( $\log \mathrm{cfu} / \mathrm{g}$ ) from the ileum

\begin{tabular}{lcccc}
\hline Variable & Control & Enzyme & Neem leaf & Bitter leaf \\
\hline THB & & & & \\
(total heterotrophic bacteria) & $9.23 \pm 0.38^{\mathrm{a}}$ & $8.52 \pm 0.33^{\mathrm{b}}$ & $8.14 \pm 0.69^{\mathrm{b}}$ & $7.94 \pm 0.38^{\mathrm{c}}$ \\
Total coliform & $7.33 \pm 0.19^{\mathrm{a}}$ & $6.00 \pm 0.46^{\mathrm{b}}$ & $4.74 \pm 0.33^{\mathrm{c}}$ & $4.84 \pm 0.52^{\mathrm{c}}$ \\
Escherichia coli & $5.65 \pm 0.11^{\mathrm{a}}$ & $3.68 \pm 0.13^{\mathrm{b}}$ & $3.44 \pm 0.16^{\mathrm{c}}$ & $3.90 \pm 0.72^{\mathrm{b}}$ \\
Salmonella & $3.24 \pm 0.31^{\mathrm{a}}$ & $2.31 \pm 0.13^{\mathrm{c}}$ & $2.51 \pm 0.12^{\mathrm{b}}$ & $2.50 \pm 0.38^{\mathrm{b}}$ \\
Lactobacillus & $6.27 \pm 0.44^{\mathrm{a}}$ & $4.44 \pm 0.30^{\mathrm{c}}$ & $4.47 \pm 0.39^{\mathrm{c}}$ & $4.83 \pm 0.12^{\mathrm{b}}$ \\
\hline
\end{tabular}

Data is expressed as mean \pm SE; means with different superscript along the same row are significantly different $(p<0.05)$ 


\section{Ofongo and Ohimain}

The population of $E$. coli was significantly $(p<0.05)$ highest in the control but similar $(p>0.05)$ among the other three treatments (enzyme, neem and bitter leaf). Salmonella population was similarly highest in the control treatment $(p<0.05)$ than the other treatments. However, values recorded for the plant extracts was comparable among $(p>0.05)$ among each other but also significantly $(p<0.05)$ higher than that recorded for enzyme supplementation (2.31 Log cfu/g). Similarly, Lactobacillus population was highest $(p<0.05)$ in the control group and not significantly $(p>0.05)$ different among the other three treatments (enzyme, neem and bitter leaf extracts).

A similar pattern was generally observed in the caecum (Table 4) where significantly $(p<0.05)$ higher population of THB (total heterotrophic bacteria) was observed in the control group. The highest THB population recorded in the control was (10.68 Log $\mathrm{cfu} / \mathrm{g})$ followed by enzyme treatment $(9.42$ Log cfu/g) and least in the neem leaf extract (8.56 Log cfu/g) and bitter leaf extract (8.27 Log $\mathrm{cfu} / \mathrm{g})$. Total coliform followed the same pattern, being highest $(p<0.05)$ in the control $(8.48 \mathrm{Log} \mathrm{cfu} / \mathrm{g})$ and least in neem (5.89 Log cfu/g) and bitter leaf (5.79- 6.00 Log cfu/g) extracts.

Table 4: Microbial count $(\log \mathrm{cfu} / \mathrm{g})$ from the Caecum

\begin{tabular}{lcccc}
\hline Variable & Control & Enzyme & Neem leaf & Bitter leaf \\
\hline THB & & & & \\
(total heterotrophic bacteria) & $10.68 \pm 0.08^{\mathrm{a}}$ & $9.42 \pm 0.16^{\mathrm{b}}$ & $8.56 \pm 0.25^{\mathrm{c}}$ & $8.27 \pm 0.48^{\mathrm{c}}$ \\
Total coliform & $8.48 \pm 0.42^{\mathrm{a}}$ & $7.31 \pm 0.41^{\mathrm{b}}$ & $6.23 \pm 0.50^{\mathrm{c}}$ & $5.89 \pm 0.09^{\mathrm{c}}$ \\
Escherichia coli & $5.55 \pm 0.39^{\mathrm{a}}$ & $3.71 \pm 0.15^{\mathrm{b}}$ & $3.91 \pm 0.72^{\mathrm{b}}$ & $3.46 \pm 0.18^{\mathrm{b}}$ \\
Salmonella & $4.10 \pm 0.49^{\mathrm{a}}$ & $3.34 \pm 0.14^{\mathrm{a}}$ & $3.55 \pm 0.12^{\mathrm{a}}$ & $3.40 \pm 0.29^{\mathrm{a}}$ \\
Lactobacillus & $6.57 \pm 0.31^{\mathrm{a}}$ & $4.98 \pm 0.53^{\mathrm{b}}$ & $4.62 \pm 0.43^{\mathrm{b}}$ & $4.81 \pm 0.12^{\mathrm{b}}$ \\
\hline
\end{tabular}

Data is expressed as mean \pm SE; means with different superscript along the same row are significantly different $(p<0.05)$ THB: total heterotrophic bacteria

Escherichia coli was highest $(p<0.05)$ in the control but was not significantly different $(p>0.05)$ among the other three treatments (enzyme, neem leaf and bitter leaf extracts). The population of Salmonella in the caecum was not significantly different $(p>0.05)$ among all the different treatments but was numerically higher in the control. Lactobacillus population exhibited the same pattern as E. coli, being highest in the control $(p<0.05)$ and similar among the other three treatments $(p>0.05)$.

The pattern of results obtained from the current study showed that the leaf extracts of neem and bitter leaves modulated the population of microbes studied both in the ileum and caecum. These plant extracts resulted in a significant $(p<0.05)$ decrease in the population of both enteropathogenic bacteria (E. coli and Salmonella). Udochukwu et al., (2015) reported the effectiveness of aqueous extract of bitter leaf against clinical isolates of resistant $E$. coli isolated. Adetunji et al. (2013) and Ghamba et al. (2014) also showed the effectiveness of different extracts of bitter leaf against clinical isolate of $E$. coli. This further corroborates the results obtained when bitter leaf extract was administered. Although not ascertained to be resistant, however, $E$. coli being a zoonotic enteropathogenic bacteria in broiler gut can be effectively managed using bitter leaf extract reducing contamination of carcasses during processing. The effectiveness of bitter leaf extract against $E$. coli has also been established by several authors (Oboh and Masodje 2009; Opara et 


\section{Effect of enzyme supplementation and plant extracts}

al., 2014). Maragathavalli et al (2012); Mamman et al (2013), Raut et al (2014); Mohammed and Omer (2015); in their respective in vitro studies showed that neem leaf extract was effective against Salmonella, E. coli and other pathogenic microbes. With the knowledge that E. coli are a common inhabitants of poultry microbiota, the gastrointestinal tract is seen as a possible reservoir for infections according to Ewers et al. 2009. Thus, any suitable alternative to antibiotics that can keep the intestinal E. coli population low is of benefit to farmers in the light of collibacillosis infection which in rare cases can present as enteritis. Wallace et al. (2010); reported various studies indicating the effects of plants and their extracts against Avian pathogenic E. coli (APEC)

The pattern of result obtained for beneficial (Lactobacillus) bacteria in the ileum and caecum of broilers administered the plant extract was not expected in the current study. This may suggest that neem leaf and bitter leaf also elicit antimicrobial effect on Lactobacillus like fresh ginger root and

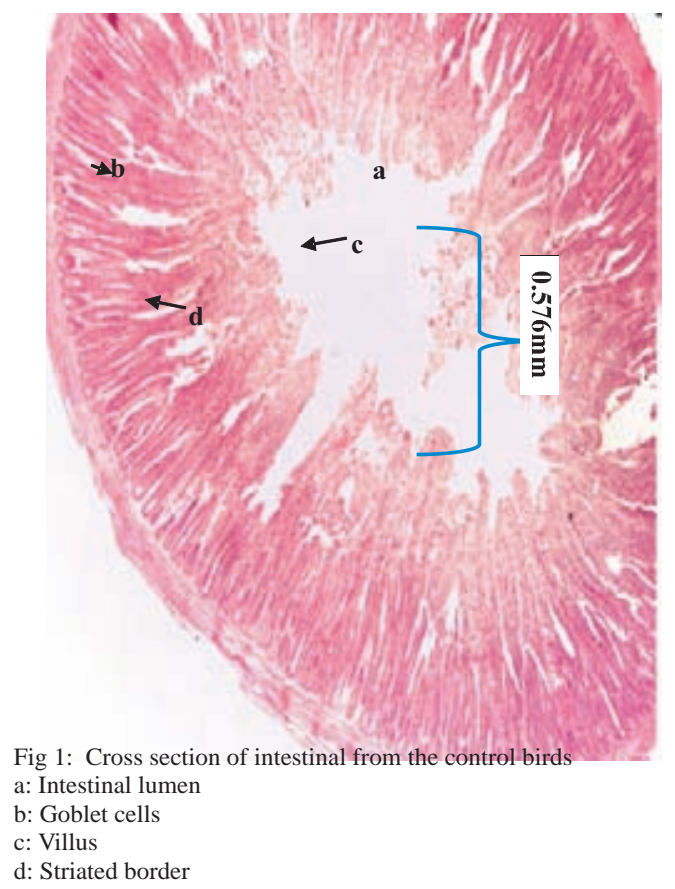

Ocimum gratissimum leaf extract as reported in previous studies by OfongoAbule and Ohimain (2015); Ohimain et al. (2015). The report of Hasshimi et al. (2014) can be best understood in the light of acidifier enhancing the growth and proliferation of certain beneficial bacteria such as lactobacillus when used in combination with plant extracts. This fact was further buttressed by Muhammed et al. (2018). It also appears that certain plant extract does have different influence on Lactobacillus population in the gut. This is evident in the report of Vidanarachchi et al. (2013). The authors reported an increase in Lactobacilli in ileum when Acacia extract and renga renga lily was administered to broiler chicken. According to Wallace et al. (2010); several factors are attributed to different results obtained from independent poultry nutritional experiments using plant extracts. Such factors as stated by the author include; poor characterization of plant materials, standardization, concentration and identity of active principle being generally unknown.

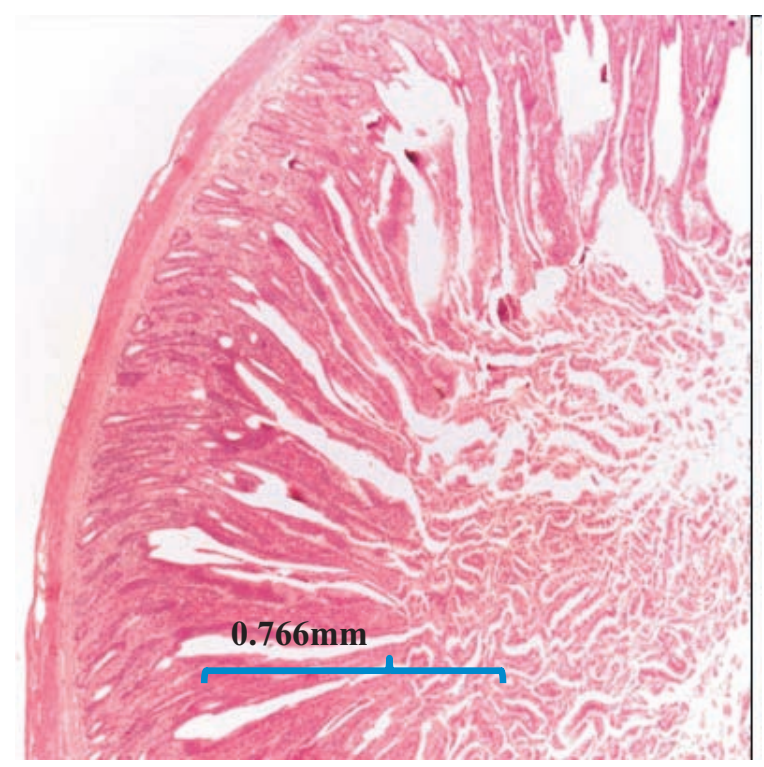

Fig 2a: Intestinal segment from broilers administered bitter leaf (Vernonia amygdylina) extract 


\section{Ofongo and Ohimain}

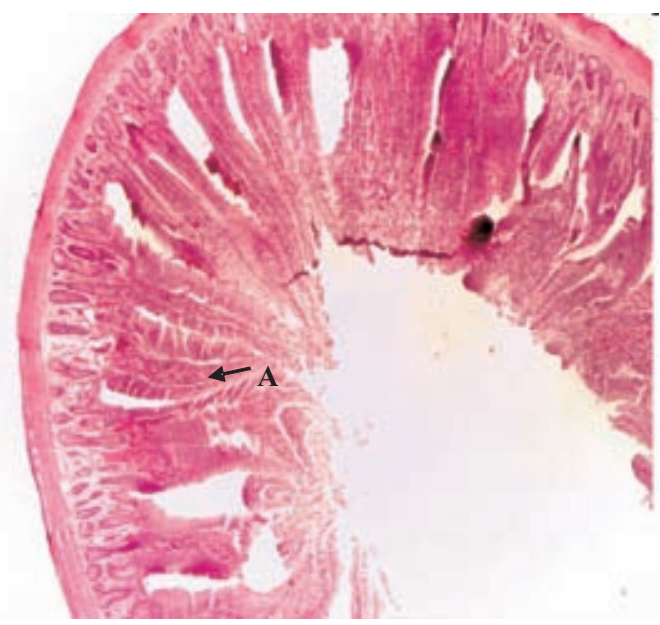

Fig 2b: Intestinal segment of birds administered bitter leaf extract. A: Blood vessels

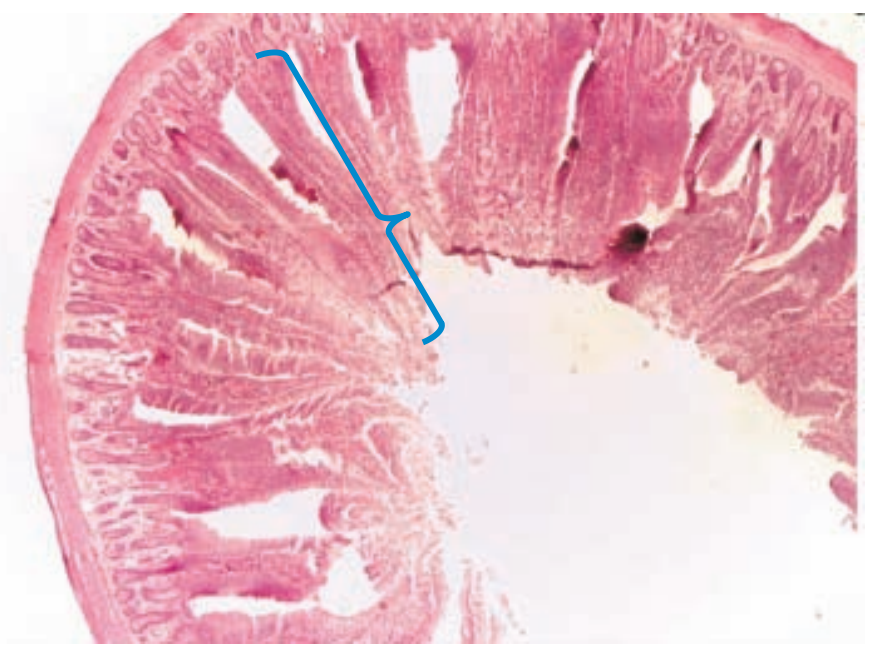

Fig 3a: Intestinal section from broilers fed enzyme supplemented diet

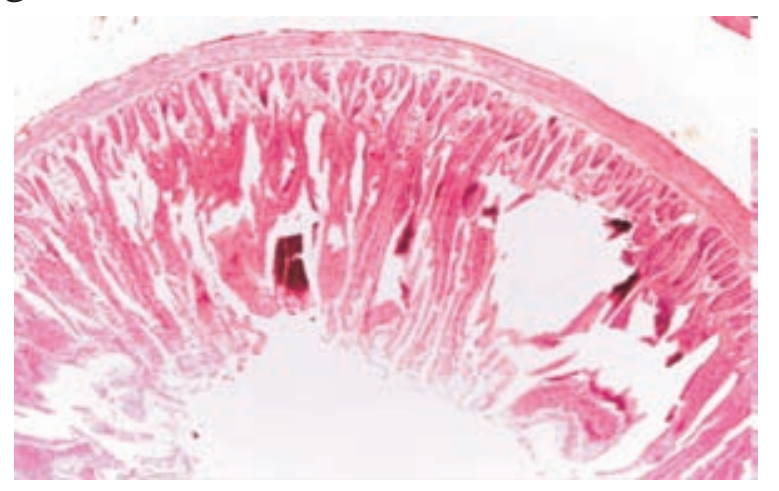

Fig 3b: Intestinal section from broilers fed enzvme supblemented diet 


\section{Effect of enzyme supplementation and plant extracts}

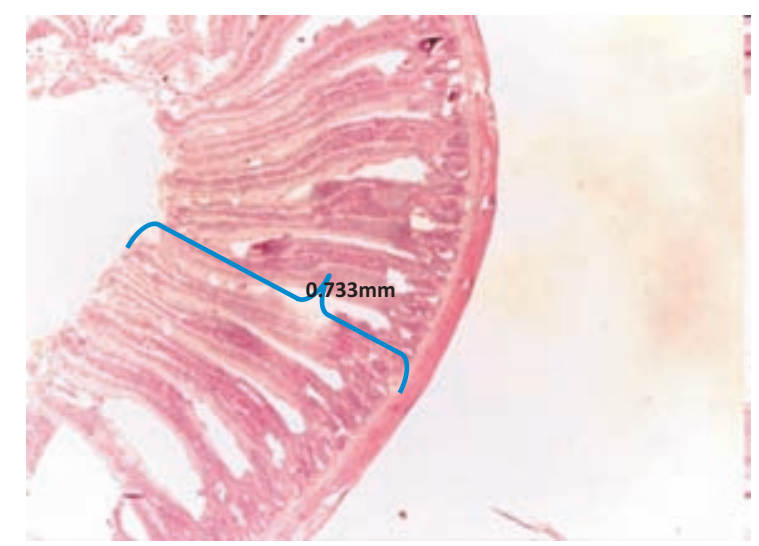

Fig 4a: Intestinal section from birds administered Neem (Azadarichta indica) leaf extracts

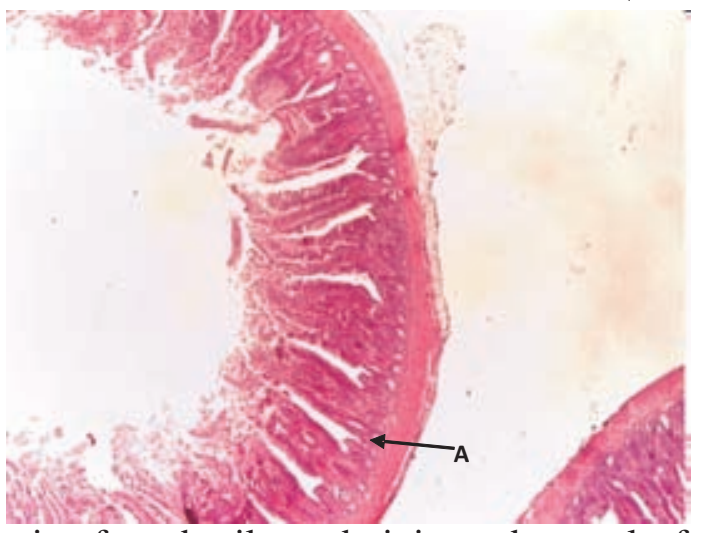

Fig 4b: Intestinal section from broilers administered neem leaf extract. A: micro villi

\section{Conclusion}

Conclusively, the enzyme and plant extract used in the current study was highly effective in lowering the population of enteropathogenic bactria $(E$. coli and Salmonella in the gut section examined respectively. The plant extract didn't elicit any detrimental effect on villus height.

\section{Acknowledgement}

This publication was based on the undergraduate research work carried out by Joy Marvellous Akinzua at Niger Delta University under the supervision of the authors. The authors also wish to thank Sylvester Izah for the editorial works.

\section{References}

Adetunji, C. O., Olaniyi, O. O. and Ogunkunle, A. T. J. 2013. Bacterial activity of crude extracts of Vernonia amygdylina on clinical isolates. Journal of Microbiology and Antimicrobials, 5(6) : 60-64.

Awad, W., Ghareeb, K. and Bohm, J. 2008. Intestinal structure and function of broiler chickens on diets supplemented with a synbiotic containing Enterococcus faecium and Oligosaccharides. Int. J. Mol. Sci. 9 : 2205-2216.

Benson, H. J. 2002. Microbiological Applications : Laboratory Manual in General Microbiology. 


\section{Ofongo and Ohimain}

Complete version, 5th edition.

McGraw-Hill, New York.

Dizaji, B. R., Zakeri, A., Golbazfarsad, A., Faramarzy, S. and Ranjbari, O. 2013. Influences of different growth promoters on intestinal morphology of broiler chickens. European Journal of Experimental Biology, 3(2) : 32- 37.

Ewers, C., Antao, E.M., Diehl, I., Philipp, H.C. and Wieler, L.H. 2009. Intestine and environment of the chicken as reservoirs for extra intestinal pathogenic Escherichia coli strains with zoonotic potential. Applied and Environmental Microbiology, 75 : 184-192.

Ghamba, P. E., Balla, H., Goje, L. J., Halidu, A. and Dauda, M. D. 2014. In vitro antimicrobial activities of Vernonia amygdylina on selected clinical isolates. Int. $J$. Curr. Microbiol. App. Sci. 3(4): 1103-1113

Hashemi, S. R., Zulkifli, I., Davoodi, H., Bejo, M. H. and Loh, T. C. 2014. Intestinal Histomorphology Changes and Serum Biochemistry Responses of Broiler Chickens Fed Herbal Plant (Euphorbia hirta) and Mix of Acidifier. Iranian Journal of Applied Animal Science, 4(1), 95-103.

Hu, H. and Guo, Y. 2008. Corticosterone administration alters small intestinal morphology and function of broiler chickens. Asian-Aust. J. Anim. Sci. 21(12) : 1773 - 1778.

Incharoen, T., Khambualai, O. and Yamauchi, K. 2009. Performance and histological changes of the intestinal vili in chickens fed dietary natural zeolite including plant extracts. Asian Journal of Poultry Science, 3(2) : 42 - 50.
Incharoen, T., Yamauchi, K., Erikawa, T. and Gotoh, H. 2010. Histology of intestinal vili and epithelial cells in chickens fed low - crude protein or low - crude fat diets. Italian Journal of Animal Science, vol. 9 : e82, 429 - 434

Laudadio, V., Passantino, L., Perillo, A., Lopresti, G., Passantino, A., Khan, R. U. and Tufarelli, V. 2012. Productive performance and histological features of intestinal mucosa of broiler chickens fed different dietary protein levels. Poultry Science, 91:265-270.

Mamman, P. H., Mshelia, W. P., Susbatrus, S. C. and Sambo, K. W. 2013. Antibacterial effects of crude extract of Azadirachta indica against Escherichia coli, Salmonella spp and Staphylococcus aureus. International Journal of Medicine and Medical Sciences, 5(1): 14-18.

Maragathavalli, S., Brindha, S., Kaviyarasi, N.S., Annadurai, B. B. and Gangwar, S. K. 2012. Antimicrobial activity in leaf extract of neem (Azadirachta indica Linn.). International Journal of Science and Nature, 3(1) : 110 - 113

Mohammed, H. A. and Omer, A. A. 2015. Antibacterial activity of Azadirachta indica (Neem) leaf extract against bacterial pathogens in Sudan. American Journal of Research Communication, 3(5): 246-251.

Muhammad N, Naeem T, and Zulfiqar A. 2018. Importance and promotion of gut health in broilers through dietary Interventions. Appro Poult Dairy \& Vet Sci. 3(1): 1 -5.

Nabizadeh, A. 2012. The effect of inulin on broiler chicken intestinal microflora, gut morphology, and 


\section{Effect of enzyme supplementation and plant extracts}

performance. Journal of Animal and Feed Sciences, 21, 2012, 725-734.

Nodu, M.B., Okpeku, M., Akpoveta, Z.A. and Iroegbu, D.O. 2016. Evaluation of Azadirachta indica leaf extract on hematology and biochemical profiles, organ weight and growth parameters of broiler chickens. Journal of New Sciences, 32(5) :1879- 1884 .

Oboh, F. O. J. and Masodje, H. I. 2009. Nutritional and Antimicrobial properties of Vernonia amygdylina leaves. International Journal of Bio-medical and Health Sciences, 5(2): $51-56$.

Ofongo - Abule, R.T.S. and Ohimain, E. I. 2015. Antimicrobial effect induced by fresh ginger root extracts in broilers. British Biotechnology Journal. 9(1): 1-6,

Ofongo - Abule, R. T. S., Etebu, E. and Ohimain, E. I. 2016. Performance and molecular identification of bacteria isolated from the gut of broiler birds after antibiotic administration and enzyme supplementation. Journal of Microbiology, Biotechnology and Food Science. Vol 6 (3): 924-929.

Ogbe, A. O, Atawodi, S. E, Abdu, P. A, Sannusi, A. and Itodo, A. E. 2009. Changes in weight, faecal oocyst count and packed cell volume of Eimeria tenella infected broilers treated Witham wild mushroom (Ganoderma lucidum) aqueous extract. Journal of South African Veterinary Association. 80 : 97102.

Ogbe, A. O. Atawodi, S. E., Abdu, P. A. Oguntayo, B. $O$ and Dus, N. 2010. Oral treatment of Eimeria tenella-infected broilers using aqueous extract of wild mushroom (Ganoderma $s p$ ) : Effect on haematological parameters and histopathology lesions. African Journal of Biotechnology 9 (52) : 8923-8927

Ogbe, A. O. and Affiku, J. P. 2012. Proximate study, mineral and antinutrient composition of Moringa oleifera leaves harvested from Lafia, Nigeria : Potential benefits in poultry nutrition and health. Journal of Microbiology, Biotechnology and Food Sciences: 1 (3) 296-308

Ohimain, E. I., Ofongo - Abule, R.T.S. and Zige, D.V. 2015. In-vitro Antibacterial effect of Ocimum gratissimum on broiler gut microflora. Bulletin of Advanced Scientific Research. $1: 37-41$

Ohimain, E. I. and Ofongo, R. T. S. 2013. Effect of enzyme supplemented diet on gut microflora, digesta $\mathrm{pH}$ and performance of broiler chickens. Journal of Microbiology, Biotechnology \& Food Science, 3 (2) : $127-131$.

Ohimain, E. I. and Ofongo, R.T. S. 2012. The effect of probiotic and prebiotic feed supplementation on chicken health and gut microflora; A review. International Journal of Animal and Veterinary Advances 4(2) : 135-143

Opara, A. U., Egbuobi, R. C., Ndudim, J. N. D., Onyewuchi, C. E. and Nnodim, J. K. 2014. Antibacterial Activity of Ocimum gratissimum (Nchu-Anwu) and Vernonia amygdalina (Bitter-Leaf). British Biotechnology Journal, 4(10) : 1115-1122.

Padihari, V. P., Tiwari, S. P., Sahu, T., Gendley, M. K. and Naik, S. K. 2014. Effects of Mannan O lig o s a c h a rid e a n d Saccharomyces cerevisiaeon Gut Morphology of Broiler Chickens. 


\section{Ofongo and Ohimain}

J. World's Poult. Res. 4(3) : 56-59

Pan, D. 2014. An integrated study on chicken gut microbiome associated with diets and feed utilization using microarray and illumina sequencing. PhD Dissertation in Graduate School of The Ohio State University

Pelicano, E. R. L., Souza, P. A., Souza, H. B. A., Figueiredo, D. F., Boiago, M. M., Carvalho, S. R. and Bordon, V. F. 2005. Intestinal mucosa development in broiler chickens fed natural growth promoters. Brazilian Journal of Poultry Science, 7 (4) : 221- 229.

Pepper, I. L. and Gerba, C. P. 2005. Environmental microbiology. A laboratory manual. Second edition. Elsevier academic press.

Raut, R. R., Sawant, A. R. and Jamge, B. B. 2014. Antimicrobial activity of Azadirachta indica (Neem) against pathogenic microorganisms. Journal of Academia and Industrial Research, 3(7) : 327 329.

Stanley, D., Hughes, R. J., Moore, R. J. 2014. Microbiota of the chicken gastrointestinal tract : Influence on health, productivity and disease. Appl Microbiol Biotechnol 98 : 4301-4310

Udochukwu, U., Omeje, F. I., Uloma, I. S., Oseiwe, F. D. 2015. Phytochemical analysis of Vernonia amygdalina and Ocimum gratissimum extracts and their antibacterial activity on some drug resistant bacteria. American Journal of Research Communication, 3(5): 225-235.

Vidanarachci, J.K., Mikkelsen, L.L., Constantinoiu, C.C., Choct, $M$. and Iji, P.A. 2013. Natural plant exacts and prebiotic compounds as alternatives to antibiotics in broiler chicken diets in a necrotic enteritis challenge model. Anim. Prod. Sci. 53 : 1247 - 1259.

Wallace, R. J., Oleszek, W., Franz, C., Hahn, I., Baser, K. H. C., Mathe, A. and Teichmann, K. 2010. 'Dietary plant bioactives for poultry health and productivity', British Poultry Science. 51 : 4, 461 $-487$.

Willis, W. L., Isikhuemhen, O. S., Minor R. C., Hurley, S. and Ohimain, E. I. 2010a. Comparing the feeding of fungus myceliated grain with other anticoccidial control measures on oocyst excretion of Eimeria challenged broilers. International Journal of Poultry Science 9 (7) : 648-651

Willis, W. L., Isikhuemhen, O. S., Ibrahim, S., King, K., Minor R. and Ohimain, E. I. 2010b. Effect of dietary fungus myceliated grain on broiler performance and enteric colonization with Bifidobacteria and Salmonella. International Journal of Poultry Science 9 (1) : 48-52

Willis, W. L., Isikhuemhen, O. S., Hurley, S. and Ohimain, E. I. 2011. Effect of phase feeding supplemental fungus myceliated grain on Oocyst excretion and performance of broiler chickens. International Journal of Poultry Science 10 (1) : 1-3

Yamauchi K., Incharoen, T. and Yamauchi, K. 2010. The Relationship between Intestinal histology and function as shown by compensatory enlargement of remnant vili after mid-gut re section in chickens. The Anatomical Record, 293 :2071-2079.

Received: $17^{\text {th }}$ October, 2018 Accepted: $10^{\text {th }}$ February, 2019 